Volume 12, Nomor 2, November 2020, pp 294-312 Copyright (C) 2017

Jurnal Akuntansi, Program Studi Akuntansi, Fakultas Ekonomi, Universitas Kristen Maranatha. ISSN 2085-8698 | e-ISSN 2598-4977. http://journal.maranatha.edu

\title{
Pengaruh Profitabilitas, Struktur Aset, Ukuran Perusahaan, Risiko Bisnis, Pertumbuhan Penjualan, Pertumbuhan Perusahaan, Likuiditas Terhadap Struktur Modal Pada Perusahaan Sektor Jasa Periode 2016-2018
}

\author{
Monica Setiawati ${ }^{1}$ \\ Fakultas Bisnis Program Studi Akuntansi Universitas Kristen Maranatha \\ (Jl. Prof. drg. Suria Sumantri, MPH No. 65, Bandung) \\ monicasetiawati1@gmail.com \\ Elvira Veronica ${ }^{2}$ \\ Fakultas Bisnis Program Studi Akuntansi Universitas Kristen Maranatha \\ (Jl. Prof. drg. Suria Sumantri, MPH No. 65, Bandung) \\ viraroca@yahoo.co.id
}

\begin{abstract}
The purpose of this research is to analyze the influence of profitability, asset structure, company size, business risk, sales growth, company growth and liquidity of the capital structure. The method used in this study is purposive sampling. The number of samples studied in this study was as much as 210 samples. The collection of data used in this study of secondary data came from the 70 financial statements of the service sector company in the period 2016-2018. Analysis of data from this study uses multiple linear regression. Based on the results of the study concluded that the asset structure has a significant positive influence on the capital structure, company growth and liquidity significantly negative effect on the capital structure, while the profitability, company size, business risk and sales growth has no influence on the capital structure.
\end{abstract}

Keywords: Profitability, Asset Structure, Company Size, Business Risk, Sales Growth, Company Growth, Liquidity and Capital Structure 


\begin{abstract}
Abstrak
Tujuan penelitian ini adalah menganalisis pengaruh profitabilitas, struktur aset, ukuran perusahaan, risiko bisnis, pertumbuhan penjualan, pertumbuhan perusahaan dan likuiditas terhadap struktur modal. Metode yang digunakan dalam penelitian ini adalah purposive sampling. Jumlah sampel yang diteliti dalam penelitian ini sebanyak 210 sampel. Pengumpulan data yang digunakan dalam penelitian ini data sekunder berasal dari laporan keuangan 70 perusahaan sektor jasa dalam periode 2016-2018. Analisis data dari penelitian ini menggunakan regresi linear berganda. Berdasarkan hasil penelitian ini disimpulkan bahwa struktur aset memiliki pengaruh positif signifikan terhadap struktur modal, pertumbuhan perusahaan dan likuiditas berpengaruh negatif signifikan terhadap struktur modal, sedangkan profitabilitas, ukuran perusahaan, risiko bisnis dan pertumbuhan penjualan tidak memiliki pengaruh terhadap struktur modal.
\end{abstract}

\title{
Kata Kunci: Profitabilitas, Struktur Aset, Ukuran Perusahaan, Risiko Bisnis, Pertumbuhan Penjualan, Pertumbuhan Perusahaan, Likuiditas dan Struktur Modal
}

\section{Pendahuluan}

Kondisi perekonomian saat ini membuat setiap perusahaan harus bersaing satu dengan lain untuk meningkatkan keuntungan yang merupakan tujuan perusahaan. Dari tujuan perusahaan ini maka setiap manajer dituntut untuk memaksimalkan kemampuannya untuk mendukung seluruh kegiatan seperti meningkatkan produksi, pemasaran, dan strategi untuk keberlanjutan perusahaan. Maka posisi manajer perusahaan ini menjadi sangat penting mengambil keputusan yang tepat bagi perusahaan. Salah satu hal penting yang perlu diperhatikan oleh manajer berkaitan dengan keputusan pendanaan. Seringkali manajer kurang memperhatikan hal ini padahal hal ini cukup berpengaruh bagi keberlangsungan perusahaan.

Keputusan pendanaan berkaitan dengan bentuk dan komposisi pendanaan yang akan dipergunakan oleh perusahaan (Husnan, 1996:253). Masalah pendanaan ini memiliki banyak hubungan dengan banyak pihak seperti kreditor, pemegang saham, dan manajemen perusahaan itu sendiri karena itu penting untuk diperhatikan. Pendanaan ini berasal dari internal serta eksternal perusahaan dimana internal berupa laba ditahan serta depresiasi serta eksternal berupa dana yang berasal dari para kreditur, pemegang surat utang dan pemilik perusahaan (Gitman, 2003:15). Kemampuan perusahaan dalam melakukan aktivitas operasinya ditentukan oleh keputusan pendanaan keuangan perusahaan yang akan berpengaruh terhadap risiko perusahaan tersebut (Joni dan Lina, 2010).

Mawikere dan Rate (2015) menyatakan bahwa manajer perusahaan diminta untuk mengidentifikasi struktur modal optimal dengan meminimalkan biaya keuangan dan memaksimalkan keuntungan yang diperoleh. Hal ini menuntut manajer untuk mampu menghimpun dan mengelola dana secara efisien dan efektif. Berdasarkan Riyanto (2001), beberapa faktor mempengaruhi struktur modal, termasuk ukuran perusahaan, pertumbuhan perusahaan, profitabilitas, pajak, manajemen, leverage, likuiditas, risiko bisnis, dan sebagainya. Penelitian ini mencoba untuk menguraikan faktor apa saja yang perlu dipertimbangkan untuk membentuk struktur modal pada perusahaan jasa yang cukup jarang diteliti. Kemudian penelitian menggunakan sampel yang menarik yaitu seluruh sektor perusahaan jasa, hal ini dikarenakan rata-rata penelitian 
menggunakan sampel perusahaan manufaktur. Selain itu penelitian ini berfokus pada tujuh faktor yang menentukan struktur modal di mana penelitian sebelumnya meneliti kurang dari tujuh faktor. Berdasarkan hal ini maka penelitian bertujuan untuk faktor-faktor yang mempengaruhi struktur modal yaitu profitabilitas, struktur aset, ukuran perusahaan, risiko bisnis, pertumbuhan penjualan, pertumbuhan perusahaan, likuiditas pada perusahaan sektor jasa yang terdaftar di Bursa Efek Indonesia (BEI) kemudian menentukan faktor mana yang terbaik untuk digunakan.

Profitabilitas memiliki pengertian yaitu kemampuan perusahaan dalam mencapai keuntungan, terkait dengan penjualan, total aset, dan ekuitas (Sartono, 2008) serta menjadi ukuran dalam menentukan tingkat efektivitas manajemen perusahaan melalui laba dari penjualan dan pendapatan investasi. Profitabilitas merupakan salah satu faktor yang memiliki pengaruh terhadap struktur modal dikarenakan semakin tinggi profitabilitas maka penggunaan hutang akan semakin kecil dan akan mengakibatkan struktur modal semakin kecil. Perusahaan yang memiliki laba ditahan yang besar akan menggunakannya sebagai modal. Sehingga laba ditahan yang besar akan memperbaiki struktur modal perusahaan dan dapat mengurangi modal dari dana eksternal (Brigham dan Houston, 2011). Profitabilitas dalam penelitian ini diukur dengan Return on Assets (ROA), dengan membandingkan pendapatan sebelum bunga dan pajak.

Struktur aset atau aktiva digunakan untuk membandingkan jumlah aset tetap dengan total aset keseluruhan perusahaan yang menggambarkan jumlah aset yang dapat dijadikan jaminan. Perusahaan yang asetnya dapat digunakan untuk digunakan sebagai jaminan untuk pinjaman cenderung menggunakan lebih banyak hutang (Brigham \& Houston, 2011) dan sebaliknya. Semakin tinggi struktur aktiva maka semakin tinggi struktur modalnya berarti semakin besar aktiva tetap yang dapat dijadikan utang oleh perusahaan tersebut (Chowdhury \& Chowdhury, 2012). Maka struktur aktiva dapat digunakan untuk menentukan seberapa besar hutang jangka panjang yang dapat diambil dan hal ini akan berpengaruh terhadap penentuan besarnya struktur modal.

Ukuran perusahaan digunakan untuk mengetahui besar atau kecilnya dari perusahaan. Ukuran ini akan menjadi acuan kegagalan atau keberhasilan perusahaan dalam mengembalikan utangnya. Perusahaan kecil lebih sulit mendapatkan pinjaman dibandingkan perusahaan besar dikarenakan risiko untuk kebangkrutannya lebih besar sehingga perusahaan besar cenderung memiliki jumlah hutang lebih tinggi namun dengan tingkat pengembalian yang besar dan akan mempengaruhi kepercayaan struktur modal mereka.

Risiko bisnis adalah risiko perusahaan ketika melaksanakan kegiatan operasionalnya, yaitu ketidakmampuan perusahaan untuk mendanai kegiatan operasinya (Gitman, 2003: 215). Risiko bisnis mempengaruhi keputusan perusahaan dalam mengambil sumber daya eksternal. Semakin tinggi risiko bisnis, semakin tinggi tingkat financial distress. Risiko bisnis dapat ditentukan dengan menggunakan DOL (Degree of Operating Leverage) dengan membandingkan total pendapatan sebelum bunga dan pajak dengan total penjualan.

Pertumbuhan penjualan adalah perubahan kenaikan atau penurunan penjualan tahun sekarang dengan tahun sebelumnya. Semakin besar pertumbuhan penjualan, maka perusahaan akan semakin berkembang sehingga akan menggunakan proporsi hutang lebih besar. Pertumbuhan penjualan yang tinggi atau stabil dapat berdampak positif pada laba perusahaan yang menjadi pertimbangan manajemen dalam menentukan struktur modal. Perusahaan dengan tingkat pertumbuhan penjualan yang tinggi akan cenderung untuk 
menggunakan hutang dalam struktur modal mereka.

Pertumbuhan perusahaan adalah jumlah kenaikan atau penurunan aset tahun sekarang dengan tahun sebelumnya. Suatu perusahaan yang berada dalam industri yang mempunyai laju pertumbuhan yang tinggi harus menyediakan modal yang cukup untuk membelanjai perusahaan. Perusahaan yang bertumbuh pesat cenderung lebih banyak menggunakan hutang daripada perusahaan yang bertumbuh secara lambat (Weston and Brigham, 1994).

Faktor terakhir yang mempengaruhi struktur modal adalah likuiditas. Likuiditas diukur dalam bentuk rasio untuk mengukur kemampuan perusahaan untuk membayar hutang jangka pendek atau hutang lancarnya yang telah jatuh tempo. Perusahaan yang dapat membayar hutangnya dalam waktu yang lebih singkat akan lebih mendapat kepercayaan dari kreditur untuk menerbitkan utang atau memberikan pendanaan dalam jumlah yang besar sehingga akan mempengaruhi struktur modal dari perusahaan itu sendiri. Bambang Riyanto (1995) menyatakan bahwa kebutuhan dana untuk aktiva lancar pada prinsipnya dibiayai dengan kredit jangka pendek.

Hasil dari penelitian ini dapat digunakan sebagai bahan pertimbangan bagi para manajer untuk mengelola struktur modal yang tepat bagi perusahaan yang dikelolanya selain itu hal ini bisa menjadi pengukuran bahan pertimbangan bagi para investor untuk berinvestasi pada suatu perusahaan. Hasil penelitian ini berkaitan erat dengan keputusan pendanaan yang sangat dibutuhkan manajer dalam mengontrol struktur modal perusahaan. perusahaan sistem evaluasi kinerja anggota organisasinya. Penelitian ini dapat juga dijadikan referensi untuk mengkaji perubahan struktur modal oleh beberapa faktor agar dapat menghasilkan keputusan yang sesuai.

\section{Kerangka Teoritis dan Hipotesis \\ Teori Struktur Modal \\ Pecking Order Theory}

Teori ini menjelaskan mengapa perusahaan akan menentukan hierarki sumber dana yang paling disukai. Teori ini pertama kali dikenalkan oleh Donaldson pada tahun 1961, sedangkan penamaan pecking order theory dilakukan oleh Myers dan Majluf pada tahun 1984. Menurut Husnan (2000:324-325), secara ringkas teori ini menyatakan bahwa: 1) perusahaan menyukai internal financing (pendanaan dari hasil operasi perusahaan); 2) perusahaan mencoba menyesuaikan rasio pembagian dividen yang ditargetkan, dengan berusaha menghindari perubahan pembayaran dividen secara drastis; 3) Kebijakan dividen ketat dimana perusahaan menetapkan jumlah pembayaran dividen dan target dividend payout ratio yang konstan. Sehingga pada periode tertentu jumlah pembayaran dividen tidak berubah, baik perusahaan untung maupun rugi; 4) Apabila pendanaan dari luar dibutuhkan, maka perusahaan akan menerbitkan sekuritas yang paling aman terlebih dahulu yang dimulai dari penerbitan obligasi, kemudian diikuti oleh sekuritas yang berkarakteristik opsi seperti obligasi konversi, baru kemudian penerbitan saham.

Menurut pecking order theory, perusahaan dengan tingkat keuntungan yang besar memiliki sumber pendanaan internal yang lebih besar dan memiliki kebutuhan untuk melakukan pembiayaan investasi melalui pendanaan eksternal yang lebih kecil (Schoubben dan Van Hulle, 2004; Adrianto dan Wibowo, 2007). Dengan demikian, teori ini memprediksikan profitabilitas berpengaruh negatif terhadap struktur modal. Berdasarkan pernyataan tersebut, maka hal ini mendasari hipotesis pertama yaitu profitabilitas berpengaruh negatif terhadap struktur modal.

Permasalahan utama dalam teori pecking order ini terletak pada asimetri informasi dan struktur aktiva merupakan variabel yang menentukan besar kecilnya 
masalah ini (Schobben dan Van Hulle, 2004; Adrianto dan Wibowo, 2007). Ketika perusahaan memiliki proporsi aktiva berwujud yang lebih besar, penilaian asetnya menjadi lebih mudah sehingga permasalahan asimetri informasi menjadi lebih rendah. Dengan demikian, perusahaan akan mengurangi penggunaan hutangnya ketika proporsi aktiva berwujud meningkat. Teori ini akan mendasari hipotesis kedua yaitu struktur aktiva berpengaruh negatif terhadap struktur modal.

Menurut teori pecking order, ukuran perusahaan diprediksikan memiliki hubungan negatif terhadap struktur modal. Menurut Smith dan Warner (1979), perusahaan besar dapat membiayai investasinya dengan mudah lewat pasar modal karena kecilnya informasi asimetri yang terjadi. Investor dapat memperoleh lebih banyak informasi dari perusahaan besar jika dibandingkan dengan perusahaan kecil. Jadi, dengan diperolehnya dana lewat pasar modal menjadikan proporsi utang menjadi semakin kecil dalam struktur modalnya. Selain itu menurut Titman dan Wessel (1988), penerbitan ekuitas pada perusahaan kecil lebih banyak mengeluarkan biaya daripada perusahaan besar. Dengan kata lain, semakin besar ukuran perusahaan, biaya penerbitan ekuitas menjadi lebih murah. Berdasarkan dukungan dari pernyataan yang dikemukakan oleh Smith dan Warner (1979) maupun Titman dan Wessel (1998), maka teori ini mendasari hipotesis ketiga yaitu ukuran perusahaan berpengaruh negatif terhadap struktur modal.

\section{Agency Theory}

Teori ini membagi pihak yang memiliki kepentingan terhadap perusahaan menjadi 2 yaitu manajemen dan pemegang saham. Manajemen adalah agen pemegang saham sebagai pemilik perusahaan (Joni, 2010) dan pemegang saham merupakan pemilik perusahaan yang menginvestasikan dananya untuk perusahaan tersebut. Para pemegang saham mengharapkan bahwa agen tidak akan bertindak atas kepentingan diri sendiri akan tetapi juga bertindak atas kemauan dari para pemegang saham, sehingga pendelegasian kewenangan pemegang saham dapat dijalankan oleh agen.

Untuk dapat menjalankan fungsinya dengan baik, manajemen harus diberi insentif dan pengawasan yang memadai. Pengawasan terhadap pihak manajemen ini akan menimbulkan biaya agensi yang ditanggung oleh pemegang saham. Menurut Wahidahwati (2002), ada beberapa alternatif untuk mengurangi agency cost salah satunya dengan meningkatkan dividend payout ratio, dengan demikian tidak tersedia cukup banyak free cash flow dan manajemen terpaksa mencari pendanaan dari luar untuk membiayai investasinya kemudian meningkatkan pendanaan dengan hutang. Hal ini mendasari hipotesis keenam yaitu kebijakan dividen akan mempengaruhi struktur modal.

\section{Signalling Theory}

Istilah sinyal (signal) dalam signalling theory diartikan sebagai suatu tindakan yang diambil oleh manajemen perusahaan yang memberikan petunjuk kepada para investor mengenai bagaimana cara pandang manajemen terhadap prospek perusahaan (Brigham dan Houston, 2006:39). Signaling theory berakar pada teori akuntansi pragmatik yang mengamati pengaruh informasi terhadap perubahan perilaku pemakai yang memperhatikan pada pengaruh informasi terhadap perubahan perilaku pemakai informasi (Suwardjono, 2005). Hal ini menunjukkan bahwa ketika perusahaan mengumumkan suatu penawaran saham baru, maka yang lebih sering terjadi, harga sahamnya akan mengalami penurunan. Studi empiris menunjukkan bahwa situasi seperti ini memang terjadi (Brigham dan Houston, 2011:186). 


\section{Trade-off Theory}

Trade-off theory dalam struktur modal adalah untuk menyeimbangkan manfaat dan pengorbanan yang muncul sebagai hasil dari penggunaan hutang. Teori ini menjelaskan adanya hubungan antara pajak, risiko kebangkrutan, dan penggunaan utang yang disebabkan keputusan struktur modal yang diambil perusahaan. Konsep trade-off menjelaskan bahwa suatu perusahaan akan meningkat seiring dengan peningkatan penggunaan leverage (akibat interest tax shields). Sampai pada suatu titik ketika ekspektasi ongkos tekanan finansial (cost of financial distress) atau ongkos kebangkrutan (bankruptcy cost) lebih besar dari interest tax shields sehingga mengurangi nilai perusahaan.

Tambahan utang masih dapat dilakukan (ditoleransi) oleh perusahaan selama manfaat yang diberikan masih lebih besar daripada biaya akibat hutang itu sendiri. Di sisi lain, teori ini juga menyatakan bahwa suatu perusahaan tidak akan mencapai nilai optimal jika pendanaan dibiayai oleh hutang sepenuhnya atau tidak menggunakan hutang sama sekali. Teori ini secara tidak langsung menyatakan bahwa perusahaan yang tidak menggunakan pinjaman sama sekali dan perusahaan yang menggunakan pembiayaan investasinya dengan pinjaman seluruhnya adalah buruk.

Secara keseluruhan teori di atas menjelaskan tentang komponen pembentuk struktur modal seperti harga saham, hutang dan lainnya, untuk hipotesis lainnya dapat dilihat pada bagian pengembangan hipotesis.

\section{Pengembangan Hipotesis \\ Pengaruh Profitabilitas Terhadap Struktur Modal}

Profitabilitas merupakan salah satu faktor yang memiliki pengaruh terhadap modal. I Made Sudana (2011:22) profitabilitas adalah kemampuan perusahaan untuk menghasilkan laba dengan menggunakan sumber-sumber yang dimiliki seperti aktiva, modal atau penjualan perusahaan. Menurut pecking order theory, perusahaan dengan tingkat keuntungan yang besar memiliki sumber pendanaan internal yang lebih besar dan memiliki kebutuhan untuk melakukan pembiayaan investasi melalui pendanaan eksternal yang lebih kecil (Adrianto dan Wibowo, 2007). Penelitian yang dilakukan Indrajaya et al. (2011), Bayunitri dan Malik (2015), Naibaho dan Azizah (2015) , Sari dan Ardini (2017) mengungkapkan bahwa profitabilitas memiliki pengaruh negatif terhadap struktur modal. maka dapat dirumuskan hipotesis sebagai berikut:

$\mathrm{H}_{1}$ : Profitabilitas memiliki pengaruh negatif terhadap struktur modal

\section{Pengaruh Struktur Aset Terhadap Struktur Modal}

Struktur aset (tangibility of Asset) merupakan perbandingan aktiva tetap terhadap total aktiva. (Brigham dan Houston, 2006: 42), menjelaskan bahwa perusahaan yang memiliki aktiva yang dapat diserahkan sebagai jaminan, cenderung menggunakan hutang dalam jumlah besar. Jika perusahaan memiliki aktiva tetap yang semakin banyak, maka perusahaan cenderung mengambil sumber daya eksternal atau utang jangka panjang dibandingkan mengambil dari modal sendiri. Hasil penelitian yang dilakukan oleh Hadianto (2008), Andika dan Sedana (2019), Indrajaya et al.(2011), Bayunitri dan Malik (2015), Sari dan Ardini (2017) menemukan bahwa struktur aset berpengaruh positif terhadap struktur modal. Maka dapat dirumuskan hipotesis sebagai berikut:

$\mathrm{H}_{2}$ : Struktur aset memiliki pengaruh positif terhadap struktur modal 


\section{Pengaruh Ukuran Perusahaan Terhadap Struktur Modal}

Ukuran perusahaan dapat diukur melalui total aktiva yang dimiliki perusahaan. Semakin besar perusahaan, semakin perusahaan membutuhkan dana yang besar untuk menunjang kegiatan operasionalnya dan salah satu alternatif pemenuhannya adalah menggunakan modal asing/utang dari pihak eksternal. Menurut Chen dan Strange (2006) dalam Indrajaya et al (2011) menemukan bahwa perusahaan yang besar lebih banyak menggunakan hutang daripada perusahaan kecil. Ini dikarenakan semakin besar perusahaan, maka lebih memiliki arus kas yang lebih stabil, yang dapat mengurangi risiko dari penggunaan utang. Pernyataan didukung oleh penelitian yang dilakukan Dewi dan Sudiartha (2017), Indrajaya et al (2011), Andika dan Sedana (2019), Wardita dan Astakoni (2018) yang menemukan bahwa ukuran perusahaan berpengaruh positif terhadap struktur modal. Tetapi dalam penelitian yang dilakukan Hadianto (2008) mengemukakan bahwa ukuran perusahaan berpengaruh negatif terhadap struktur modal. Berdasarkan pernyataan diatas dapat dirumuskan hipotesis:

$\mathrm{H}_{3}$ : Ukuran perusahaan memiliki pengaruh positif terhadap struktur modal

\section{Pengaruh Risiko Bisnis Terhadap Struktur Modal}

Risiko bisnis mempengaruhi keputusan perusahaan dalam mengambil sumber daya eksternal. Semakin tinggi risiko bisnis, semakin tinggi tingkat financial distress. Risiko bisnis dapat ditentukan dengan menggunakan DOL (Degree of Operating Leverage). Menurut Agus Sartono (2005:262) dalam Bayunitri dan Malik (2015) risiko bisnis adalah risiko ketidakpastian tingkat EBIT (Earning Before Income Taxes) yang diperoleh. Perubahan EBIT dipengaruhi oleh banyak faktor, salah satunya adalah DOL (Degree of Operating leverage). Semakin tinggi EBIT (Earning Before Income Taxes) maka
DOL (Degree of Operating Leverage) semakin tinggi. Hasil penelitian yang dilakukan oleh Indrajaya et al (2011), Bayunitri dan Malik (2015) menemukan bahwa risiko bisnis berpengaruh positif terhadap struktur modal. Maka dapat dirumuskan hipotesis:

$\mathrm{H}_{4}$ : Risiko bisnis berpengaruh positif terhadap struktur modal

\section{Pengaruh Pertumbuhan Penjualan Terhadap Struktur Modal}

Pertumbuhan penjualan adalah perbedaan penjualan dari tahun ke tahun dan merupakan indikator keberhasilan permintaaan dan daya saing pasar. Semakin tinggi tingkat pertumbuhan penjualan suatu perusahaan, semakin besar pula kebutuhannya akan pembiayaan tambahan. Demikian pula, semakin kecil rasio retensi, semakin besar kebutuhannya untuk dana tambahan (Brigham dan Daves (2009)). Pernyataan tersebut didukung oleh penelitian yang dilakukan Sari dan Ardini (2017) dan Naibaho et al. (2015) yang menemukan bahwa pertumbuhan penjualan memiliki pengaruh positif terhadap struktur modal. Maka dapat dirumuskan hipotesis:

$\mathrm{H}_{5}$ : Pertumbuhan penjualan memiliki pengaruh positif terhadap struktur modal

\section{Pengaruh Pertumbuhan Perusahaan Terhadap Struktur Modal}

Suatu perusahaan yang berada dalam industri yang mempunyai laju pertumbuhan yang tinggi harus menyediakan modal yang cukup untuk membelanjai perusahaan. Perusahaan yang bertumbuh pesat cenderung lebih banyak menggunakan utang daripada perusahaan yang bertumbuh secara lambat (Weston and Brigham, 1994). Ozkan (2001) juga menemukan bahwa jumlah utang yang dikeluarkan oleh perusahaan berbanding terbalik dengan pertumbuhan. Hasil penelitian tersebut juga konsisten dengan hasil penelitian oleh Bhaduri (2002) serta Brailsford (2002). Sehingga dalam penelitian ini, pertumbuhan 
perusahaan mempunyai pengaruh negatif terhadap struktur modal.

$\mathrm{H}_{6}$ : Pertumbuhan perusahaan memiliki pengaruh negatif terhadap struktur modal.

\section{Pengaruh Likuiditas Terhadap Struktur Modal}

Suatu perusahaan mengutamakan untuk meningkatkan modal secara internal dengan menginvestasikan kembali laba bersihnya lalu menjual sekuritas jangka pendeknya yang dapat dipasarkan. Ketika persediaan dana telah habis, perusahaan akan menerbitkan hutang dan mungkin saham preferen. Perusahaan akan mengeluarkan saham biasa sebagai pilihan terakhir menurut pecking order theory (Brigham dan Daves 2009:525). Semakin likuid aktiva yang dimiliki perusahaan, maka semakin kecil kemungkinan perusahaan menggunakan pendanaan eksternal. Hasil penelitian dilakukan oleh Adiyana dan Ardiana (2014) dan Wijaya dan Hadianto (2008) menemukan bahwa liabilitas memiliki pengaruh positif signifikan terhadap struktur modal. Dari hasil-hasil penelitian tersebut maka dapat dirumuskan hipotesis:

$\mathrm{H}_{7}$ : Likuiditas memiliki pengaruh positif terhadap struktur modal

Secara garis besar rumusan hipotesis penelitian dapat dilihat dari model penelitian di bawah ini:

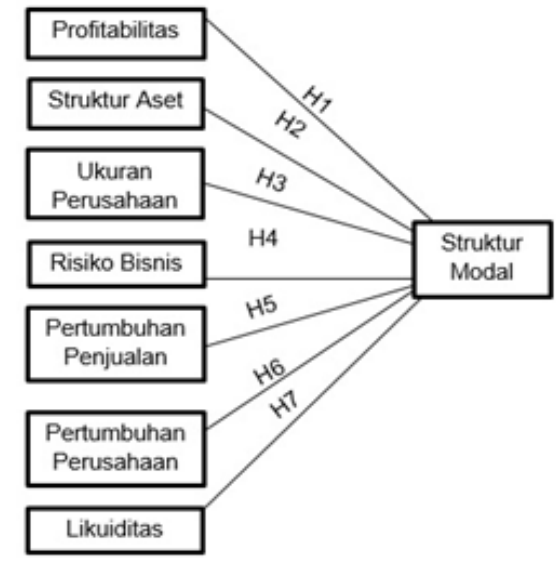

\section{Metode Penelitian}

\section{Data dan Sampel}

Penelitian ini berasal dari 428 perusahaan industri sektor jasa yang terdaftar di Bursa Efek Indonesia (BEI) tahun 2016-2018 dengan kriteria pemilihan sampel berasal dari perusahaan yang memiliki IPO di bawah tahun 2017 serta menerbitkan secara terus menerus laporan keuangan yang telah diaudit per 31 Desember dalam periode penelitian. Metode dari penelitian ini adalah tidak langusng berupa data arsip yaitu data kuantitatif dalam publikasi laporan keuangan dari perusahaan industri barang konsumsi yang terdaftar di Bursa Efek Indonesia (BEI) selama periode 20162018.

Sampel dalam penelitian adalah 70 perusahaan sektor jasa yang terdiri dari sub sektor properti dan real estate; infrastruktur, utilitas dan transportasi; keuangan; perdagangan, jasa dan investasi yang diambil secara purposive sampling dengan sub sektor perdagangan, jasa dan industri yang memiliki proporsi terbesar $(38,59 \%)$, kemudian properti dan real estate $(19,53 \%)$, infrastruktur, utilitas dan transportasi $(18,59 \%)$, keuangan (23,29\%). Dalam penelitian ini, metode yang digunakan adalah metode data arsip. Sumber data yang digunakan dalam penelitian ini adalah data sekunder yang berasal dari laporan keuangan perusahaan jasa yang 
terdaftar di Bursa Efek Indonesia selain itu dengan menggunakan penelitian kepustakaan (library research) dengan memahami jurnal-jurnal dan buku-buku yang berhubungan dengan topik penelitian. Sumber dari data penelitian ini diperoleh dari www.idx.co.id dan www.sahamok.com pada periode 2016 hingga 2018.

\section{Model Empiris dan Variabel}

Penelitian ini bersifat asosiatif dengan tujuan menganalisis hubungan dua variabel atau lebih. Tujuan penelitian ini adalah mengetahui pengaruh variabel independen yaitu profitabilitas (X1), struktur aset (X2), ukuran perusahaan (X3), risiko bisnis (X4), pertumbuhan penjualan (X5), stabilitas penjualan (X6) dan risiko bisnis (X7), terhadap variabel dependen struktur modal (Y). Objek penelitian ini adalah struktur modal perusahaan industri sektor jasa yang terdaftar di Bursa Efek Indonesia.

Variabel struktur modal dalam penelitian ini mengacu pada financial leverage, dimana financial leverage dapat diartikan sebagai besarnya beban tetap keuangan (finansial) yang digunakan oleh perusahaan, dan beban tetap tersebut biasanya berasal dari pembayaran bunga untuk utang yang digunakan oleh perusahaan (Hanafi, 2004:332) dalam Indrajaya et al (2011)). Dalam penelitian ini variabel struktur modal dihitung berdasarkan nilai buku. Menurut Song (2005) dalam Indrajaya et al (2011), penggunaan nilai buku dibandingkan nilai pasar tidak terlalu menjadi masalah.

Debt equity ratio $=\frac{\text { Total hutang }}{\text { Total ekuitas }}$

Profitabilitas diukur dengan rasio dari Return on Asset (ROA), yaitu perbandingan antara keuntungan (laba) yang diperoleh perusahaan terkait sumber daya atau total aset dengan cara membagi antara laba bersih dengan total aset perusahaan sektor jasa di Bursa Efek
Indonesia periode 2016-2018 yang dinyatakan dalam persentase (\%).

Return On $\quad$ Asset
$=\frac{\text { Earning before interest tax }}{\text { Total aset }} \times 100 \%$

Struktur aset dihitung dengan fixed asset ratio yang membandingkan antara aset tetap dengan total aset (Naibaho dkk., 2015) yang dimiliki perusahaan sektor jasa di Bursa Efek Indonesia periode 2016-2016 dan dinyatakan dalam persentase (\%).

Struktur Aset $=\frac{\text { Ahtiva tetap }}{\text { Total ahtiva }} \times 100 \%$

Ukuran perusahaan merupakan ukuran besar atau kecilnya aset yang dimiliki perusahaan yang diukur dengan dinyatakan dalam persentase (\%). Ukuran perusahaan ini menggunakan nilai buku. Rasio ini digunakan dalam penelitian yang dilakukan oleh Indrajaya et al (2011), rasio ini dapat dirumuskan:

Firm size $=$ Ln total asset

Risiko bisnis dapat ditentukan dengan menggunakan DOL (Degree of Operating Leverage). DOL dihitung dengan cara membagi persentase perubahan EBIT dibagi dengan persentase perubahan dari sales.

Degree Operating Leverage $=\frac{\Delta E B I T}{\Delta \text { Sales }}$

Pertumbuhan penjualan dihitung dengan perbandingan selisih penjualan pada waktu t dengan t-1 dibagi penjualan t-1 (Angelina, 2016). Pertumbuhan penjualan dihitung dari setiap perusahaan sektor jasa di Bursa Efek Indonesia periode 2016-2018 yang dinyatakan dalam persentase (\%). 
Pertumbuhan

Penjualan

$=\frac{\text { Penjualan }_{\mathrm{i}}-\text { Penjualan }_{\mathrm{i}-1}}{\text { Penjuglan }_{\mathrm{f}}-1} \times 100 \%$

Pertumbuhan perusahaan dihitung dengan membandingkan selisih jumlah aset tahun ini dengan tahun sebelumnya pada setiap perusahaan sektor jasa di Bursa Efek Indonesia periode 2016-2018 yang dinyatakan dalam persentase (\%).

GROW $=\frac{T A_{\mathrm{L}}-T A_{\mathrm{L}-1}}{T A_{\bar{T}-1}} \times 100 \%$

Likuiditas diukur dengan current ratio, yaitu perbandingan antara aset lancar dengan hutang lancar perusahaan sektor jasa di Bursa Efek Indonesia periode 20162018 yang dinyatakan dalam persentase (\%).

Current ratio $=\frac{\text { Aktiva lanear }}{\text { Hutang lanear }} \times 100 \%$

Teknik analisis data yang digunakan dalam penelitian ini adalah model regresi linier berganda dengan menggunakan SPSS. Model regresi linier merupakan pendekatan yang digunakan untuk memodelkan hubungan antara variabel dependen (Y) dan satu atau lebih variabel independen $(\mathrm{X})$ sehingga dapat menjelaskan hubungan antara variabel profitabilitas (X1),struktur aset (X2), ukuran perusahaan (X3), risiko bisnis (X4), pertumbuhan penjualan (X5), stabilitas penjualan (X6) dan risiko bisnis (X7) terhadap struktur modal (Y) pada perusahaan industri sektor jasa di Bursa Efek Indonesia (BEI). Karakteristik yang digunakan dalam penelitian ini adalah Explanatory Research yang melihat hubungan antara variabelvariabel penelitian (independen dan dependen) dan menguji hasil dari hipotesis yang telah dirumuskan.

\section{Definisi Variabel}

\begin{tabular}{|c|c|c|}
\hline Variable & Simbol & Definisi \\
\hline \multicolumn{3}{|r|}{ Independent variable } \\
\hline Profitabilitas & ROA & $\begin{array}{l}\text { Ukuran tingkat keuntungan yang diperoleh terkait penjualan dan } \\
\text { investasi. }\end{array}$ \\
\hline Struktur Aset & SA & $\begin{array}{l}\text { Kekayaan atau sumber daya ekonomi yang dimiliki oleh suatu } \\
\text { perusahaan diharapkan dapat memberikan manfaat di masa depan } \\
\text { Terdiri dari aset tetap, aset tidak berwujud, aset lancar, dan aset } \\
\text { tidak lancar. }\end{array}$ \\
\hline Ukuran Perusahaan & FS & Total aset perusahaan. \\
\hline Risiko Bisnis & $\mathrm{DOL}$ & $\begin{array}{l}\text { Persentase perubahan EBIT dibandingkan dengan perubahan } \\
\text { penjualan. }\end{array}$ \\
\hline $\begin{array}{l}\text { Pertumbuhan } \\
\text { Penjualan }\end{array}$ & PP & $\begin{array}{l}\text { Peningkatan jumlah penjualan dari tahun ke tahun atau dari waktu ke } \\
\text { waktu. }\end{array}$ \\
\hline $\begin{array}{l}\text { Pertumbuhan } \\
\text { perusahaan }\end{array}$ & GROW & $\begin{array}{l}\text { Rasio perubahan total aset periode sekarang dengam periode } \\
\text { sebehumnya terhadap total aset sebelumnya. }\end{array}$ \\
\hline Likuiditas & CR & Kemampuan untuk memenuhi kewajiban finansial. \\
\hline \multicolumn{3}{|r|}{ Dependent variable } \\
\hline Struktur Modal & DER & $\begin{array}{l}\text { Saldo jumlah utang jangka pendek permanen, utang jangka panjang. } \\
\text { saham preferen, dan saham biasa. }\end{array}$ \\
\hline
\end{tabular}

\section{Hasil Dan Pembahasan}

Untuk melihat pengaruh variabel independen $\mathrm{X}$ terhadap variabel dependen $\mathrm{Y}$, maka dilakukan pengujian secara simultan dan parsial. Pengujian teknik pengolahan data yang digunakan adalah:

\section{Uji Statistik Deskriptif}

\section{Tabel 1}

\begin{tabular}{|l|r|r|r|r|r|}
\hline & N & Minimum & Maximum & Mean & $\begin{array}{c}\text { Std. } \\
\text { Deviation }\end{array}$ \\
\hline X1 & 210 & -5093 & 760 & $-16,477$ & 362,6825 \\
X2 & 210 & 0,01 & 2,07 & 0,3651 & 0,44757 \\
X3 & 210 & 14,54 & 38,35 & 28,382 & 3,61504 \\
X4 & 210 & $-71,23$ & 38,93 & 0,5765 & 10,37973 \\
X5 & 210 & $-2,54$ & 4,12 & 0,1542 & 0,63152 \\
X6 & 210 & $-4,65$ & 36,03 & 0,2733 & 2,6151 \\
X7 & 210 & 0,06 & 62,21 & 3,8253 & 7,16104 \\
Y & 210 & 0,01 & 64,84 & 2,8037 & 7,20549 \\
Valid N & 210 & & & & \\
(listwise) & & & & \\
\hline
\end{tabular}

Berdasarkan tabel 1 diketahui bahwa jumlah sampel yang diteliti sebanyak 210 sampel berdasarkan laporan keuangan periode 2016 sampai 2018.

Profitabilitas (X1) memiliki nilai tertinggi sebesar 760 dan nilai terendah sebesar 5093 dengan nilai rata-rata (mean) sebesar 16.4774 dengan deviasi standar sebesar 362.68251 . 
Struktur Aset (X2) memiliki nilai tertinggi sebesar 2.07 dan nilai terendah sebesar 0.01 dengan nilai rata-rata (mean) sebesar 0.3651 dengan standar deviasi sebesar 0.44757 .

Ukuran perusahaan (X3) memiliki nilai tertinggi sebesar 38.35 dan nilai terendah sebesar 14.54 dengan nilai ratarata (mean) sebesar 28.3820 dengan standar deviasi sebesar 3.61504.

Risiko bisnis (X4) memiliki nilai tertinggi sebesar 38.93 dan nilai terendah sebesar - 71.23 dengan nilai rata-rata (mean) sebesar 0.5765 dengan standar deviasi sebesar 10.37973 .

Pertumbuhan penjualan (X5) memiliki nilai tertinggi sebesar 4.12 dan nilai terendah sebesar -2.54 dengan nilai rata-rata (mean) sebesar 0.1542 dengan standar deviasi sebesar 0.63152 .

Pertumbuhan penjualan (X6) memiliki nilai tertinggi sebesar 36.03 dan nilai terendah sebesar -4.65 dengan nilai rata-rata (mean) sebesar 0.2733 dengan standar deviasi sebesar 2.61510.

Likuiditas (X7) memiliki nilai tertinggi sebesar 62.21 dan nilai terendah sebesar 0.06 dengan nilai rata-rata (mean) sebesar 3.8253 dengan standar deviasi sebesar 7.16104.

Struktur modal (Y) memiliki nilai tertinggi sebesar 64.84 dan nilai terendah sebesar 0.01 dengan nilai rata-rata (mean) sebesar 2.8037 dengan standar deviasi sebesar 7.20549.

\section{Uji Asumsi Klasik Uji Normalitas}

Tabel 2

\begin{tabular}{|ll|r|}
\hline & & $\begin{array}{r}\text { Unstandardi } \\
\text { zed Residual }\end{array}$ \\
\hline $\mathrm{N}$ & Mean & 204 \\
Normal & Std. Deviation & 0,6437329 \\
Parameters ${ }^{\mathrm{a}, \mathrm{b}}$ & Absolute & 0,059 \\
Most Extreme & Positive & 0,054 \\
Differences & Negative & $-0,059$ \\
& & 0,059 \\
Test Statistic & &, $078^{\circ}$ \\
Asymp. Sig. (2-tailed) &
\end{tabular}

a. Test distribution is Normal.

b. Calculated from data.

c. Lilliefors Significance Correction.

Uji normalitas bertujuan untuk melihat apakah nilai residual berdistribusi normal atau tidak (Ghozali, 2013). Menurut Ghozali (2013), untuk mendeteksi normalitas dapat dilakukan dengan uji Kolmogorov-Smirnov. Berdasarkan uji normalitas dengan menggunakan OneSample Kolmogorov-Smirnov Test yang ditampilkan pada tabel 2 menunjukkan bahwa besarnya nilai tes statistik sebesar 0,059 dimana Asymp. Sig. (2-tailed) lebih besar dari tingkat signifikansi $(0,05)$ yaitu 0,078. Maka pada penelitian ini mengindikasikan bahwa data yang digunakan berdistribusi normal, sehingga dapat disimpulkan bahwa model regresi memenuhi asumsi normalitas. 


\section{Uji Multikolinearitas}

Tabel 3

\begin{tabular}{|c|c|c|c|c|c|c|c|}
\hline \multirow{2}{*}{ Model } & \multicolumn{2}{|c|}{$\begin{array}{l}\text { Unstandardized } \\
\text { Coefficients }\end{array}$} & \multirow{2}{*}{\begin{tabular}{|c|}
$\begin{array}{c}\text { Standardized } \\
\text { Coefficients }\end{array}$ \\
Beta \\
\end{tabular}} & \multirow{2}{*}{$\mathrm{t}$} & \multirow{2}{*}{ Sig. } & \multicolumn{2}{|c|}{ Collinearity Statistics } \\
\hline & B & $\begin{array}{l}\text { Std. } \\
\text { Error }\end{array}$ & & & & Tolerance & VIF \\
\hline (Constant) & $-0,839$ & 0,381 & & $-2,203$ & 0,029 & & \\
\hline $\mathrm{X} 1$ & $-1,94 \mathrm{E}-06$ & 0 & $-0,001$ & $-0,015$ & 0,988 & 0,974 & 1,026 \\
\hline $\mathrm{X}_{2}$ & 0,5 & 0,104 & 0,302 & 4,832 & 0 & 0,985 & 1,015 \\
\hline X3 & 0,024 & 0,013 & 0,119 & 1,863 & 0,064 & 0,945 & 1,058 \\
\hline${ }^{1} \mathrm{X} 4$ & 0,003 & 0,005 & 0,043 & 0,677 & 0,499 & 0,969 & 1,032 \\
\hline $\mathrm{X} 5$ & $-0,062$ & 0,075 & $-0,053$ & $-0,829$ & 0,408 & 0,95 & 1,052 \\
\hline $\mathrm{X} 6$ & $-0,037$ & 0,018 & $-0,132$ & $-2,082$ & 0,039 & 0,955 & 1,048 \\
\hline $\mathrm{X} 7$ & $-0,47$ & 0,091 & $-0,334$ & $-5,147$ & 0 & 0,913 & 1,095 \\
\hline
\end{tabular}

Uji multikolinearitas digunakan untuk menentukan apakah ada korelasi yang tinggi antara variabel independen dalam model regresi linier berganda. Jika ada korelasi yang tinggi antara variabel independen, hubungan antara variabel independen dan variabel dependen terganggu. Berdasarkan tabel dapat diketahui bahwa semua variabel bebas yaitu $\mathrm{X} 1, \mathrm{X} 2, \mathrm{X} 3, \mathrm{X} 4, \mathrm{X} 5, \mathrm{X} 6$, serta $\mathrm{X} 7$ memiliki nilai tolerance kurang dari 0,10 dan namun nilai VIF kurang dari 10. Berdasarkan tabel 3 maka persamaan linear tersebut telah bebas dari gejala multikolinearitas.

\section{Uji Autokorelasi}

\section{Tabel 4}

\begin{tabular}{|r|r|r|r|r|r|}
\hline Model & $\mathrm{R}$ & R Square & $\begin{array}{c}\text { Adjusted } \\
\text { R Square }\end{array}$ & $\begin{array}{c}\text { Std. } \\
\text { Error of } \\
\text { the } \\
\text { Estimate }\end{array}$ & $\begin{array}{l}\text { Durbin- } \\
\text { Watson }\end{array}$ \\
\hline 1 &, $448^{\mathrm{a}}$ & 0,201 & 0,101 & 1,09167 & 1,99 \\
\hline
\end{tabular}

Menurut Ghozali (2013) uji autokorelasi bertujuan menguji apakah dalam model regresi linear ada korelasi antara kesalahan pengganggu pada periode $t$ dengan kesalahan pengganggu pada periode $\mathrm{t}-1$ (sebelumnya). Jika terjadi korelasi, maka dinamakan ada problem autokorelasi. Autokorelasi muncul karena observasi yang berurutan sepanjang waktu berkaitan satu sama lainnya. Dengan level signifikansi sebesar 0,05 dan $\mathrm{N}=204$ dan jumlah variabel bebas $\mathrm{k}=7$, maka diperoleh nilai $\mathrm{du}=1,8413$ diperoleh nilai $(4-\mathrm{du})$ sebesar $4-1,8413=2,1587$. Oleh karena dalam tabel 4 nilai Durbin Watson sebesar 1,990 berada diantara 1,8413 dan 2,1587 sehingga dapat disimpulkan bahwa data terbebas dari gejala autokorelasi.

\section{Uji Heteroskedastisitas}

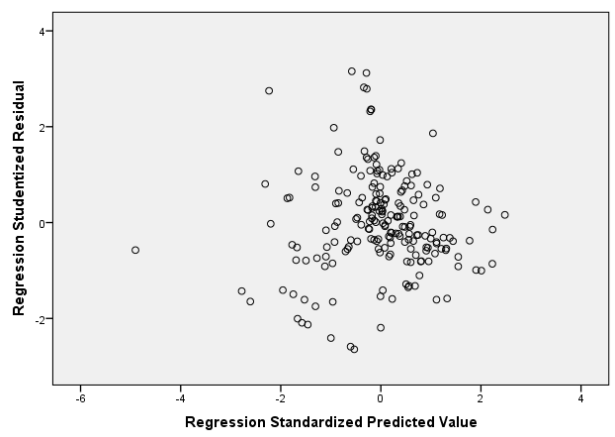

\section{Gambar 1}

Uji Heteroskedastisitas

Uji heteroskedastisitas bertujuan untuk menguji apakah dalam model regresi terjadi ketidaksamaan variance dari residual satu pengamatan ke pengamatan yang lain. Jika variance dari residual satu pengamatan ke pengamatan lain tetap, maka disebut Homoskedastisitas dan jika berbeda disebut Heteroskedastisitas. Berdasarkan gambar 1 dapat dilihat bahwa titik-titik data menyebar di atas dan di bawah atau di sekitar angka 0 secara acak, Titik-titik data tidak mengumpul hanya di atas atau di bawah saja, Hal ini dapat disimpulkan bahwa tidak terjadi heteroskedastisitas pada model regresi, sehingga model regresi layak dipakai 


\section{Persamaan Regresi}

\section{Tabel 5}

\begin{tabular}{|c|r|r|r|r|r|}
\hline \multirow{2}{*}{ Model } & \multicolumn{2}{|c|}{$\begin{array}{c}\text { Unstandardized } \\
\text { Coefficients }\end{array}$} & $\begin{array}{c}\text { Standardized } \\
\text { Coefficients }\end{array}$ & \multicolumn{1}{c|}{$\mathrm{t}$} & \multirow{2}{*}{ Sig. } \\
\cline { 2 - 4 } & \multicolumn{1}{|c|}{ B } & \multicolumn{1}{|c|}{$\begin{array}{c}\text { Std. } \\
\text { Error }\end{array}$} & Beta & & \\
\hline (Constant) & $-0,839$ & 0,381 & & $-2,203$ & 0,029 \\
ROA & $-1,94 \mathrm{E}-06$ & 0 & $-0,001$ & $-0,015$ & 0,988 \\
SA & 0,5 & 0,104 & 0,302 & 4,832 & 0 \\
1 FS & 0,024 & 0,013 & 0,119 & 1,863 & 0,064 \\
DOL & 0,003 & 0,005 & 0,043 & 0,677 & 0,499 \\
PP & $-0,062$ & 0,075 & $-0,053$ & $-0,829$ & 0,408 \\
GROW & $-0,037$ & 0,018 & $-0,132$ & $-2,082$ & 0,039 \\
CR & $-0,47$ & 0,091 & $-0,334$ & $-5,147$ & 0 \\
\hline
\end{tabular}

Persamaan regresi linier berganda:

$\mathrm{Y}_{\mathrm{i}, \mathrm{t}}=\alpha_{0}+\beta_{1} \mathrm{X} 1_{\mathrm{i}, \mathrm{t}}+\beta_{2} \mathrm{X} 2_{\mathrm{i}, \mathrm{t}}+\beta_{3} \mathrm{X} 3_{\mathrm{i}, \mathrm{t}}+\beta_{4}$

$X 4_{i, t}+\beta_{5} X 5_{i, t}+\beta_{6} X 6_{i, t}+\beta_{7} X 7_{i, t}+E_{i, t}$

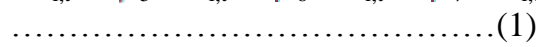

$\mathrm{Y}_{\mathrm{i}, \mathrm{t}}=\alpha_{1}+\beta_{8} \mathrm{X} 1_{\mathrm{i}, \mathrm{t}}+\epsilon_{\mathrm{i},}$

$\mathrm{Y}_{\mathrm{i}, \mathrm{t}}=\alpha_{2}+\beta_{9} \mathrm{X} 2_{\mathrm{i}, \mathrm{t}}+\mathrm{E}_{\mathrm{i}, \mathrm{t}}$

$\mathrm{Y}_{\mathrm{i}, \mathrm{t}}=\alpha_{3}+\beta_{10} \mathrm{X} 3_{\mathrm{i}, \mathrm{t}}+\mathrm{E}_{\mathrm{i}, \mathrm{t}}$

$\mathrm{Y}_{\mathrm{i}, \mathrm{t}}=\alpha_{4}+\beta_{11} \mathrm{X} 4_{\mathrm{i}, \mathrm{t}}+\epsilon_{\mathrm{i}, t}$

$Y_{i, t}=\alpha_{5}+\beta_{12} X 5_{i, t}+E_{i, t}$

$Y_{i, t}=\alpha_{6}+\beta_{13} X 6_{i, t}+E_{i, t}$

$\mathrm{Y}_{\mathrm{i}, \mathrm{t}}=\alpha_{7}+\beta_{14} \mathrm{X} 7_{\mathrm{i}, \mathrm{t}}+\mathrm{E}_{\mathrm{i}, \mathrm{t}}$

Di mana:

$\mathrm{Y}_{\mathrm{i}, \mathrm{t}} \quad=$ Struktur modal di perusahaan $\mathrm{i}$ pada tahun $\mathrm{t}$

$\mathrm{X} 1_{\mathrm{i}, \mathrm{t}}=$ Profitabilitas di perusahaan $\mathrm{i}$ pada tahun $\mathrm{t}$

$\mathrm{X} 2_{\mathrm{i}, \mathrm{t}}=$ Struktur aset di perusahaan $\mathrm{i}$ pada tahun $\mathrm{t}$

$\mathrm{X} 3_{\mathrm{i}, \mathrm{t}}=$ Ukuran perusahaan $\mathrm{di}$ perusahaan i pada tahun $\mathrm{t}$

$\mathrm{X} 4_{\mathrm{i}, \mathrm{t}}=$ Risiko bisnis di perusahaan $\mathrm{i}$ pada tahun $\mathrm{t}$

$\mathrm{X} 5_{\mathrm{i}, \mathrm{t}}=$ Pertumbuhan penjualan $\mathrm{di}$ perusahaan i pada tahun $\mathrm{t}$

$\mathrm{X}_{\mathrm{i}, \mathrm{t}} \quad=\quad$ Pertumbuhan perusahaan di perusahaan i pada tahun $\mathrm{t}$

$\mathrm{X} 7_{\mathrm{i}, \mathrm{t}} \quad=$ Tingkat likuiditas $\mathrm{di}$ perusahaan i pada tahun $\mathrm{t}$

$\alpha_{0}-\alpha_{7}=$ konstanta

$\beta_{1}-\beta_{14}=$ koefisien

$\epsilon_{\mathrm{i}, \mathrm{t}} \quad=$ variabel pengganggu perusahaan

306
Dari tabel 5, maka diperoleh persamaan sebagai berikut:

$Y_{i, t}=-0,839-1,936 E-6 X 1_{i, t}+0,500 X 2_{i, t}+$
$0,024 X 3_{i, t}+0,003 X 4_{i, t}-0,062 X 5_{i, t}-$
$0,037 X 6_{i, t}-0,470 X 7_{i, t}+\epsilon_{i, t} \ldots \ldots \ldots .(1)$
$Y_{i, t}=-0,094-1,376 E-5 X 1_{i, t}+\epsilon_{i, t} \ldots .(2)$
$Y_{i, t}=-0,260+0,457 X 2_{i, t}+\epsilon_{i, t} \ldots \ldots . .(3)$
$Y_{i, t}=-1,011+0,032 X 3_{i, t}+E_{i, t} \ldots \ldots .(4)$
$Y_{i, t}=-0,093-0,001 X 4_{i, t}+E_{i, t} \ldots \ldots .(5)$
$Y_{i, t}=-0,086-0,050 X 5_{i, t}+E_{i, t} \ldots \ldots .(6)$
$Y_{i, t}=-0,079-0,054 X 6_{i, t}+E_{i, t} \ldots \ldots .(7)$
$Y_{i, t}=0,025-0,501 X 7_{i, t}+\epsilon_{i, t} \ldots \ldots .(8)$

Arti dari persamaan diatas adalah

$\alpha_{0}=-0,839$ artinya jika nilai variabel X1 (ROA), X2 (SA), X3 (FS), X4 (DOL), X5 (PP), X6 (GROW), dan X7 (CR) sama dengan nol, maka Y (DER) sama dengan 0,839 .

$\alpha_{1}=-0,094$ artinya jika nilai variabel X1 (ROA) sama dengan nol, maka Y (DER) sama dengan $-0,094$.

$\alpha_{2}=-0,260$ artinya jika nilai variabel $\mathrm{X} 2$ (SA) sama dengan nol, maka Y (DER) sama dengan $-0,260$.

$\kappa_{3}=-1,011$ artinya jika nilai variabel X3 (FS) sama dengan nol, maka Y (DER) sama dengan $-1,011$.

$\alpha_{4}=-0,093$ artinya jika nilai variabel $\mathrm{X} 4$ (DOL) sama dengan nol, maka Y (DER) sama dengan $-0,093$.

$\alpha_{5}=-0,086$ artinya jika nilai variabel X5 (PP) sama dengan nol, maka Y (DER) sama dengan $-0,086$.

$\alpha_{6}=-0,079$ artinya jika nilai variabel X6 (GROW) sama dengan nol, maka Y (DER) sama dengan $-0,079$.

$\alpha_{7}=0,025$ artinya jika nilai variabel $\mathrm{X} 7$ (CR) sama dengan nol, maka Y (DER) sama dengan 0,025 .

$\beta_{1=}-1,936 \mathrm{E}-6$ memiliki arti jika nilai variabel X1 (ROA) meningkat sebesar satu satuan, maka Y (DER) akan menurun sebesar -1,936E-6 dengan asumsi variabel independen lain sama dengan nol. 
$\beta_{2}=0,500$ memiliki arti jika nilai variabel $\mathrm{X} 2$ (SA) meningkat sebesar satu satuan, maka Y (DER) akan meningkat sebesar 0,500 dengan asumsi variabel independen lain sama dengan nol.

$\beta_{3}=0,024$ memiliki arti jika nilai variabel X3 (FS) meningkat sebesar satu satuan, maka Y (DER) akan meningkat sebesar 0,024 dengan asumsi variabel independen lain sama dengan nol.

$\beta_{4}=0,003$ memiliki arti jika nilai variabel X4 (DOL) meningkat sebesar satu satuan, maka Y (DER) akan meningkat sebesar 0,003 dengan asumsi variabel independen lain sama dengan nol.

$\beta_{5}=-0,062$ memiliki arti jika nilai variabel X5 (PP) meningkat sebesar satu satuan, maka Y (DER) akan menurun sebesar 0,062 dengan asumsi variabel independen lain sama dengan nol.

$\beta_{6}=-0,037$ memiliki arti jika nilai variabel X6 (GROW) meningkat sebesar satu satuan, maka Y (DER) akan menurun sebesar 0,037 dengan asumsi variabel independen lain sama dengan nol.

$\beta_{7}=-0,037$ memiliki arti jika nilai variabel X7 (CR) meningkat sebesar satu satuan, maka Y (DER) akan menurun sebesar 0,037 dengan asumsi variabel independen lain sama dengan nol.

$\beta_{8}=-1,376 \mathrm{E}-$ memiliki arti jika nilai variabel X1 (ROA) meningkat sebesar satu satuan, maka Y (DER) akan menurun sebesar 1,376E-5.

$\beta_{9}=0,457$ memiliki arti jika nilai variabel X2 (SA) meningkat sebesar satu satuan, maka Y (DER) akan meningkat sebesar 0,457 .

$\beta_{10}=0,032$ memiliki arti jika nilai variabel X3 (FS) meningkat sebesar satu satuan, maka Y (DER) akan meningkat sebesar 0,032 .

$\beta_{11}=-0,001$ memiliki arti jika nilai variabel X4 (DOL) meningkat sebesar satu satuan, maka Y (DER) akan menurun sebesar 0,001 .

$\beta_{12}=-0,050$ memiliki arti jika nilai variabel X5 (PP) meningkat sebesar satu satuan, maka Y (DER) akan menurun sebesar 0,050 .

$\beta_{13}=-0,054$ memiliki arti jika nilai variabel X6 (GROW) meningkat sebesar satu satuan, maka Y (DER) akan menurun sebesar 0,054 .

$\beta_{14}=-0,501$ memiliki arti jika nilai variabel X7 (CR) meningkat sebesar satu satuan, maka Y (DER) akan menurun sebesar 0,501 .

\section{Uji Statistik F}

Tabel 6

\begin{tabular}{|c|c|c|c|c|c|}
\hline Model & \begin{tabular}{|c|} 
Sum of \\
Squares
\end{tabular} & $\mathrm{df}$ & $\begin{array}{c}\text { Mean } \\
\text { Square }\end{array}$ & F & Sig. \\
\hline $\begin{array}{l}\text { Regressio } \\
\mathrm{n}\end{array}$ & 27,646 & 7 & \multirow{3}{*}{$\begin{array}{l}3,949 \\
0,429\end{array}$} & \multirow[t]{3}{*}{9,202} & \multirow[t]{3}{*}{, $000^{b}$} \\
\hline${ }^{1}$ Residual & 84,122 & 196 & & & \\
\hline Total & 111,767 & 203 & & & \\
\hline
\end{tabular}

Berdasarkan Tabel 6. nilai signifikan $\mathrm{F}$ bernilai 0,000 kurang dari 0,05 (0,000< $0,05)$ dengan nilai $F$ hitung yakni 9,202 dan $\mathrm{F}$ tabel dengan derajat kebebasan $\mathrm{N}-\mathrm{k}=204$ $-8=196$ dan $\mathrm{k}-1=8-1=7$ yakni 2,06 Karena nilai $\mathrm{F}$ hitung > F tabel $(9,202>$ 2,78) Maka variabel profitabilitas, struktur aset, ukuran perusahaan, risiko bisnis, pertumbuhan penjualan, pertumbuhan perusahaan, likuiditas secara simultan berpengaruh terhadap struktur modal.

\section{Uji Signifikan Parameter Individual (Uji Statistik T)}

Berdasarkan Tabel 5 dapat dilihat bahwa variabel profitabilitas (ROA) memiliki nilai $\beta 1$ sebesar $1,936 \mathrm{E}-6$ bernilai negatif serta besar signifikansi 0,988 lebih besar dibandingkan dengan 0,05 maka H1 ditolak, dengan kata lain profitabilitas secara parsial tidak berpengaruh terhadap struktur modal.

Strukur aset (SA) memiliki nilai $\beta 2$ sebesar 0,5 yang bernilai positif serta besar signifikansi 0,00 lebih kecil dibandingkan dengan 0,05 maka $\mathrm{H} 2$ diterima, dengan kata lain struktur aset secara parsial berpengaruh terhadap struktur modal. 
Ukuran perusahaan (FS) memiliki nilai $\beta 3$ sebesar 0,024 yang bernilai positif serta besar signifikansi 0,064 lebih besar dibandingkan dengan 0,05 maka H3 ditolak, dengan kata lain ukuran perusahaan secara parsial tidak berpengaruh terhadap struktur modal.

Risiko bisnis (DOL) memiliki nilai $\beta 4$ sebesar 0,003 yang bernilai positif serta besar signifikansi 0,499 lebih kecil dibandingkan dengan 0,05 maka H4 ditolak, dengan kata lain risiko bisnis secara parsial tidak berpengaruh terhadap struktur modal.

Pertumbuhan penjualan (PP) memiliki nilai $\beta 5$ sebesar $-0,062$ yang bernilai negatif serta besar signifikansi 0,408 lebih besar dibandingkan dengan 0,05 maka H5 ditolak, dengan kata lain pertumbuhan penjualan (PP) secara parsial tidak berpengaruh terhadap struktur modal.

Pertumbuhan perusahaan (GROW) memiliki nilai $\beta 6$ sebesar $-0,037$ yang bernilai negatif serta besar signifikansi 0,039 lebih kecil dibandingkan dengan 0,05 maka H6 diterima, dengan kata lain pertumbuhan perusahaan (GROW) secara parsial berpengaruh terhadap struktur modal.

Likuiditas (CR) memiliki nilai $\beta 7$ sebesar -0,47 yang bernilai negatif serta besar signifikansi 0,00 lebih kecil dibandingkan dengan 0,05 maka H7 ditolak, dengan kata lain likuiditas (CR) secara parsial berpengaruh terhadap struktur modal.

\section{Koefisien Determinasi}

\section{Tabel 8}

\begin{tabular}{|c|c|c|c|c|}
\hline Model & $\mathrm{R}$ & R Square & $\begin{array}{c}\text { Adjusted } \\
\text { R Square }\end{array}$ & $\begin{array}{c}\text { Std. } \\
\text { Error of } \\
\text { the } \\
\text { Estimate }\end{array}$ \\
\hline 1 &, $497^{\mathrm{a}}$ & 0,247 & 0,22 & 0,65513 \\
\hline
\end{tabular}

Berdasarkan tabel 8 , nilai Adjusted $R$ Square senilai 0,220 yang menunjukkan 308 bahwa tinggi rendahnya struktur modal (DER) dapat dijelaskan oleh variabel profitabilitas (ROA), struktur aset (SA), ukuran perusahaan (FS), risiko bisnis (DOL), pertumbuhan penjualan (PP), pertumbuhan perusahaan (GROW) dan likuiditas (CR) sebesar 22\% sedangkan sisanya sebesar $78 \%$ dijelaskan oleh sebabsebab lain di luar model. Korelasi (R) menunjukkan angka 0,497 yang artinya hubungan antara profitabilitas (ROA), struktur aset (SA), ukuran perusahaan (FS), risiko bisnis (DOL), pertumbuhan penjualan (PP), pertumbuhan perusahaan (GROW) dan likuiditas (CR) terhadap struktur modal (DER) adalah cukup berarti.

\section{Penutup}

\section{Ringkasan}

Berdasarkan hasil penelitian, maka penelitian ini dapat diringkas sebagai berikut:

1. Profitabilitas (ROA) tidak berpengaruh terhadap struktur modal (DER) pada perusahaan sektor jasa dibuktikan dari signifikansinya sebesar 0,988>0,05

2. Struktur aset (SA) berpengaruh positif terhadap struktur modal (DER) pada perusahaan sektor jasa yang dilihat dari $\beta 2$ sebesar 0,5 serta signifikansinya sebesar $0,00<0.05$

3. Ukuran perusahaan (FS) tidak berpengaruh terhadap struktur modal (DER) pada perusahaan sektor jasa yang dibuktikan dari signifikansinya sebesar $0,064>0.05$

4. Risiko bisnis (DOL) tidak berpengaruh terhadap struktur modal (DER) pada perusahaan sektor jasa yang dilihat dari signifikansinya sebesar 0,499 >0,05

5. Pertumbuhan penjualan (PP) tidak berpengaruh terhadap struktur modal (DER) pada perusahaan sektor jasa yang dibuktikan dari signifikansinya sebesar 0,408>0.05

6. Pertumbuhan perusahaan (GROW) berpengaruh negatif terhadap struktur modal (DER) pada perusahaan sektor jasa yang dibuktikan dari $\beta 6$ sebesar - 
0,037 serta signifikansinya sebesar $0,039<0,05$

7. Likuiditas (CR) berpengaruh negatif terhadap perusahaan sektor jasa yang dibuktikan dari $\beta 3$ sebesar $-0,47$ serta signifikansinya sebesar $0,00<0,05$

8. Berdasarkan tabel 9, nilai Adjusted $R$ Square senilai 0,220 yang menunjukkan bahwa tinggi rendahnya struktur modal (DER) dapat dijelaskan oleh variabel profitabilitas (ROA), struktur aset (SA), ukuran perusahaan (FS), risiko bisnis (DOL), pertumbuhan penjualan (PP), pertumbuhan perusahaan (GROW) dan likuiditas (CR) sebesar $22 \%$ sedangkan sisanya sebesar $78 \%$ dijelaskan oleh sebabsebab lain di luar model.

9. Korelasi (R) menunjukkan angka 0,497 yang artinya hubungan antara profitabilitas (ROA), struktur aset (SA), ukuran perusahaan (FS), risiko bisnis (DOL), pertumbuhan penjualan (PP), pertumbuhan perusahaan (GROW) dan likuiditas (CR) terhadap struktur modal (DER) adalah cukup berarti.

\section{Diskusi}

Penelitian ini bertujuan untuk mengetahui pengaruh profitabilitas, struktur aset, ukuran perusahaan, risiko bisnis, pertumbuhan penjualan, pertumbuhan perusahaan, tingkat likuiditas terhadap struktur modal. Dari hasil penelitian menujukkan bahwa struktur aset memiliki pengaruh positif signifikan terhadap struktur modal, pertumbuhan perusahaan dan likuiditas berpengaruh negatif signifikan terhadap struktur modal, sedangkan faktor lainnya yaitu profitabilitas, ukuran perusahaan, risiko bisnis dan pertumbuhan penjualan tidak memiliki pengaruh signifikan terhadap struktur modal. Dengan demikian hasil penelitian ini mendukung hasil dari penelitian Hadianto (2008), Bhaduri (2002), Brailsford (2002). Selain itu penelitian ini selaras dengan teori trade-off. Namun penelitian ini tidak sejalan dengan penelitian Sari dan Ardini (2017), Dewi dan Sudiartha (2017), Indrajaya et al (2011), Naibaho et al. (2015), Wijaya dan Hadianto (2008) serta teori ini tidak selaras dengan teori pecking order. Hal ini dikarenakan struktur modal perusahaan jasa berbeda dengan strukur modal perusahaan manufaktur jika dilihat dari segi modal ataupun aset yang dimiliki perusahaan jasa jauh lebih sedikit dibandingkan dengan perusahaan manufaktur contohnya perusahaan manufaktur membutuhkan peralatan untuk kegiatan produksinya sedangkan perusahaan jasa tidak. Dengan demikian maka penelitian selanjutnya dapat mengubah pengukuran struktur modal perusahaan dengan rasio WACC (Weighted Average Cost of Capital), dapat memberikan kategori tertentu dalam pengambilan data untuk menghindari data outlier serta dapat memperluas periode penelitian, menambah variabel seperti biaya utang, biaya keagenan, kepemilikan internal, kepemilikan eksternal, kepemilikan institusional, dan pajak perusahaan, kondisi pasar, sikap manajemen.

\section{Simpulan dan Saran}

\section{Simpulan}

Berdasarkan hasil penelitian maka dapat disimpulkan bahwa struktur aset, pertumbuhan perusahaan dan likuiditas berpengaruh terhadap struktur modal, sedangkan faktor lainnya yaitu profitabilitas, ukuran perusahaan, risiko bisnis dan pertumbuhan penjualan tidak memiliki pengaruh terhadap struktur modal.

\section{Keterbatasan}

1. Periode dalam penelitian ini terbatas yaitu 3 tahun sehingga hasilnya mungkin belum maksimal atau mengalami bias akibat beberapa perubahan signifikan yang tidak dapat 
tercatat melalui periode pengamatan yang singkat tersebut.

2. Teknik pengambilan sampel dalam penelitian ini secara purposive sampling yang membatasi sampelnya perusahaan sektor jasa yang memiliki IPO di bawah 2017 sehingga hasilnya kurang menggambarkan perusahaan sektor lain secara keseluruhan.

\section{Saran}

1. Pihak perusahaan disarankan dapat lebih memperhatikan faktor struktur aktiva (SA), pertumbuhan perusahaan (GROW) dan likuiditas (CR) dalam menentukan struktur modal perusahaan.

2. Investor dapat lebih memperhatikan struktur aktiva (SA), pertumbuhan perusahaan (GROW) dan likuiditas (CR) dalam menentukan keputusan untuk berinvestasi pada suatu perusahaan.

\section{Daftar Pustaka}

Andika, I Kadek Rico, dan Ida Bagus Panji Sedana. "Tujuan dari penelitian ini adalah untuk menganalisis signifikansi pengaruh profitabilitas, struktur aktiva , dan ukuran perusahaan terhadap struktur modal. Penelitian ini dilakukan pada Perusahaan Makanan dan Minuman di Bursa Efek Indonesia (BEI) periode." Jurnal Manajemen 8, no. 9 (2019): 5803-24.

Dewi, D., dan G. Sudiartha. "Pengaruh Profitabilitas, Ukuran Perusahaan, Dan Pertumbuhan Aset Terhadap Struktur Modal Dan Nilai Perusahaan." E-Jurnal Manajemen Universitas Udayana 6, no. 4 (2017): 242635.

Dewiningrat, Ayu Indira, dan I Ketut Mustanda. "Pengaruh Likuiditas, Profitabilitas, Pertumbuhan Penjualan, Dan Struktur Aset
Terhadap Struktur Modal.” E-Jurnal Manajemen Universitas Udayana 7, no. 7 (2018): 3471. https://doi.org/10.24843/EJMUNUD .2018.v07.i07.p02.

Farisa, Nurul Anggun, dan Listyorini Wahyu Widati. "Analisa Profitabilitas, Likuiditas, Pertumbuhan Penjualan, Struktur Aktiva Dan Kebijakan Dividen Terhadap Struktur Modal." Prosiding Seminar Nasional Multi Disiplin Ilmu \& Call For Papers UNISBANK Ke-3 (SENDI_U 3), no. 2011 (2017): 640-49.

Ginting, Christy Ulina, dan Widi Hidayat. "The effect of a fraudulent financial statement, firm size, profitability, and audit firm size on audit delay." International Journal of Innovation, Creativity and Change 9, no. 7 (2019): 323-41.

Hadianto, Bram. "Pengaruh Struktur Aktiva, Profitabilitas, Dan Ukuran Perusahaan Terhadap Struktur Modal Emiten Sektor Telekomunikasi Periode 20002006:," 2006, 1-15.

Indrajaya, Glenn, Herlina, dan Rini Setiadi. "Akurat Jurnal Ilmiah Akuntansi Nomor 06 Tahun ke-2 SeptemberDesember 2011." Jurnal Ilmiah Akuntansi, no. 6 (2011): 1-23.

Indrajaya, Glenn, Herlina dan Rini Setiadi . 2011. "Pengaruh Struktur Aktiva, Ukuran Perusahaan, Tingkat Pertumbuhan, Profitabilitas dan Risiko Bisnis Terhadap Struktur Modal (Studi Empiris Pada Perusahaan Sektor Pertambangan yang Listing di Bursa Efek Indonesia Periode 2004-2007)". Jurnal Ilmiah Akuntansi, No.6.

Juliantika, Ni, dan Made Dewi. "Pengaruh Profitabilitas, Ukuran Perusahaan, Likuiditas, Dan Risiko Bisnis Terhadap Struktur Modal Pada Perusahaan Property Dan 
Realestate." None 5, no. 7 (2016): 251028.

Lubis, Ignatius Leonardus, Bonar $\mathrm{M}$ Sinaga, dan Hendro Sasongko. "Pengaruh Profitabilitas, Sruktur Modal, Dan Likuiditas Terhadap Nilai Perusahaan." Jurnal Aplikasi Bisnis dan Manajemen 3, no. 3 (2017): 458-65. https://doi.org/10.17358/jabm.3.3.45 8.

M. Sienly Veronica Wijaya dan Bram Hadianto. (2008). "Pengaruh Struktur Aktiva, Ukuran, Likuiditas, dan Profitabilitas terhadap Struktur Modal Emiten Sektor Ritel di Bursa Efek Indonesia : sebuah Pengujian Hipotesis Pecking Order". Jurnal Ilmiah Akuntansi, 7(1), 71-84

Maha Dewi, Dewa Ayu Intan Yoga; Sudiartha, Gede Mertha. 2017. "Pengaruh Profitabilitas, Ukuran Perusahaan, Dan Pertumbuhan Aset Terhadap Struktur Modal Dan Nilai Perusahaan". E-Jurnal Manajemen, [S.L], V. 6, no 4 P. 2222 - 2252. Issn 2302-8912.

Maryanti, Eny. "Analisis Profitabilitas, Pertumbuhan Perusahaan, Pertumbuhan Penjualan Dan Struktur Aktiva Terhadap Struktur Modal Pada Perusahaan Sektor Industri Barang Konsumsi Yang Terdaftar Di Bursa Efek Indonesia (Studi Empiris Pada Perusahaan Manufaktur yang Terdaftar di Bursa Efek Indonesia Tahun 2012-2014)." Riset Akuntansi dan Keuangan Indonesia 1, no. 2 (2016): 143-51. https://doi.org/10.23917/reaksi.v1i2. 2730.

Naibaho, Andreas, Topowijono, dan Devi Farah Azizah. "Pengaruh Profitabilitas, Pertumbuhan Penjualan, Struktur Aktiva Dan Ukuran Perusahaan Terhadap Struktur Modal (Studi Kasus pada Perusahaan Property and Real Estate yang terdaftar di BEI tahun 2011-
2013)." Jurnal Administrasi Bisnis (JAB) Vol. 28, no. 1 (2015): No. 1. administrasibisnis.studentjournal.ub. ac.id.

Nicko, Ida, dan Putu Ardiana. "Pengaruh Ukuran Perusahaan, Risiko Bisnis, Pertumbuhan Aset, Profitabilitas Dan Tingkat Likuiditas Pada Struktur Modal." E-Jurnal Akuntansi 10, no. 1 (2014): 14-30.

Rate, Paulina Van, dan Cinthia Yurike Mawikere. "Pengaruh Stabilitas Penjualan Dan Struktur Aktiva Terhadap Struktur Modal Perusahaan Automotive and Allied Product Yang Terdaftar Di Bei Periode 2010-2013." Jurnal Riset Ekonomi, Manajemen, Bisnis dan Akuntansi 3, no. 3 (2015): 149-59.

Sari, Mila Diana, Djumahir A, dan Atim Djazuli. "Pengaruh Profitabilitas, Ukuran Perusahaan, Pertumbuhan Penjualan, Struktur Aset, Non-Debt Tax Shield Dan Usia Perusahaan Terhadap Struktur Modal (Studi Pada Perusahaan Makanan Dan Minuman Di BEI)." Ekonomi Bisnis 20, no. 1 (2015): 22-32. https://doi.org/10.17977/um042v20i 1p22-32.

Sari,Retno Indah dan Lilis Ardini. 2017."Pengaruh StrukturAktiva, Risiko Bisnis, Pertumbuhan Penjualan,Dan Profitabilitas Terhadap Struktur Modal. Jurnal Ilmu dan Riset Akuntansi Volume 6, No. 7 ISSN : 2460-0585.

Setiana, Esa. "Analisis Faktor-Faktor Yang Mempengaruhi Struktur Modal Pada Perusahaan Manufaktur Yang Listing Di Bursa Efek Indonesia (Bei)." Jurnal Keuangan dan Bisnis 04, no. 03 (2012): 192-204.

Sudana , I Made. 2011. Manajemen Keuangan Perusahaan Teori dan Praktek. Jakarta : Erlangga Brigham, Eugene F \& Houston. 2006. Manajemen Keuangan Buku II. Erlangga, Jakarta. 
Triyono, Anindita Kusumastuti, dan Indarti Diah Palupi. "the Influence of Capital Structure and Firm Size on Profitability and Dividend Policy." Riset Akuntansi dan Keuangan Indonesia 4, no. 3 (2019): 101-11. https://doi.org/https://doi.org/10.239 17/reaksi.v4i3.9340.

Wijaya, Hadianto. 2008. "Pengaruh Struktur Aktiva, Ukuran, Likuiditas, dan profitabilitas terhadap Struktur Modal Emiten Sektor Ritel di BEI: Sebuah pengujian Hipotesis Pecking Order". Jurnal Ilmiah Akuntansi, 7 (1) : 71-82

Wijaya, Sienly Veronica, dan Bram Hadianto. "Pengaruh Struktur Aktiva, Ukuran, Likuiditas Dan Profitabilitas Terhadap Struktur Modal Emiten Sektor Ritel Di Bursa Efek Indonesia (Sebuah Pengujian Hipotesis Pecking Order)." Jurnal Akuntansi Maranatha, 2008.. 